Research, part of a Special Feature on The Recent History and Practice of Local Fisheries in a Globalizing World

\title{
Long-term, Ecosystem-Scale Changes in the Southern Benguela Marine Pelagic Social-Ecological System: Interaction of Natural and Human Drivers
}

\author{
$\underline{\text { Astrid Jarre }}^{I}, \underline{\text { Sven M. Ragaller }}^{l}$ and Laurence Hutchings $^{l}$
}

\begin{abstract}
South Africa's small pelagics fishery is currently the largest in volume and second largest in value in the southern Benguela. It exploits short-lived, small pelagic fishes such as anchovy (for reduction into fish meal and oil) and sardine (for reduction as well as human consumption through canned products), and to a lesser extent redeye round herring and mesopelagics, largely for reduction. We explore the recent history (1940s to present) of the social-ecological system around this fishery. The natural subsystem, at the scales of the ocean environment and the ecosystem, is characterized by high interannual and documented decadal-scale variability. We characterize the human social subsystem at the scales of the fishing industry, legislation, and west coast fishing towns, and demonstrate interdependencies between the natural and social subsystems by following system-scale changes. The pelagic fishing industry has evolved to deal with variability through consolidation, diversification, and range expansion. Legislation has increasingly looked for conservation of the resource while ensuring economic viability of the industry, and hence factory- and vessel-related jobs. Fishing communities under apartheid stayed largely dependent on company-generated infrastructure, combining seasonal employment in the fishing factories with inshore fishing, targeting rock lobster and line fish. While the pelagic industry persisted and communities survived, the resource base for both offshore and inshore fisheries gradually eroded. The advent of democracy in the mid-1990s brought allocation of long-term fishing rights to individuals or companies under conditions of depleted inshore resources aggravated by a shift in the distribution of pelagic fish away from the west coast towards the Cape south coast in the second half of the 1990s. The resultant loss of employment and fishing rights in the inshore has generated community coping strategies that include poaching and challenges to the current Marine Living Resources Act, while the industry continues to expand by range and species, possibly further eroding the resource base. We argue that the situation in the pelagic social-ecological system is indicative of further loss of resilience to change. Coping with future longterm, system-scale change will necessitate careful long-term scenario planning among the various interest groups involved, joint research being one way to overcome the communications breakdown and initiate the joint planning process.
\end{abstract}

Key Words: anchovy; coastal communities; inshore fishery; marine social-ecological systems; purse seining; rock lobster; small pelagic fishery; South Africa; Southern Benguela; sardine

\section{INTRODUCTION}

South Africa's small pelagics fishery, operating in the southern Benguela Current Large Marine Ecosystem, is currently the largest fishery by volume and second largest in value in the country. It developed quickly after the Second World War, with St. Helena Bay on the west coast as its center (Figure 1), producing fishmeal and oil, as well as canned fish, for national as well as international markets (e.g., Lees 1969). The fishery exploits short-lived, small pelagic fishes such as sardine (Sardinops sagax) (for human consumption through canned products, as well as reduction into fish meal and oil) and anchovy (Engraulis encrasicolus) (for reduction only), and to a lesser extent redeye round herring (Etrumeus whiteheadi) and mesopelagics, largely for reduction. The population size of small pelagics can fluctuate widely from one year to the next, partly because environmental conditions influence the recruitment of juvenile fish into the fishery, and partly through the influence of fishing on the parent fish population.
The impact of environmental variables (wind, ocean temperature, upwelling of nutrient-rich ocean water from the deep sea onto the shelf) on the distribution and recruitment of small pelagic fish has long been known. In addition to interannual variability, decadal-scale environmental conditions have been documented as favoring one species over another or both species simultaneously (van der Lingen et al. 2006a, $b$ ). Recent research has focused on determining decadal-scale environmental (oceanographic) conditions and how and when they change (tipping points), as well as the impact of such changes at the scale of the entire ecosystem (Howard et al. 2007, Blamey et al. 2012). Decadal-scale variability is important for management purposes, because human activities in the ocean should be managed according to the prevailing regime in the ecosystem (e.g., King and McFarlane 2006). However, for appropriate fisheries management advice in social-ecological systems, natural variability and change also need to be placed in historical perspective alongside social changes related to fishing. A recent review of the available 
scientific information (Hutchings et al. 2012), rather than indicating the unidirectional change over the past 60 years that could be expected from climate change projections, has concluded instead that, while there are strong decadal-scale changes in the physical and biological oceanography of the South African west coast, the only persistent change has been that in the fish community, which has largely been affected by fishing.

Fig. 1. South Africa's southwestern Cape coast. Note that "St. Helena" and "Saldanha" are used here to distinguish the positions of the towns from the large bays adjacent to them, i.e., St. Helena Bay and Saldanha Bay. In practice, the names are used interchangeably for town and bay.

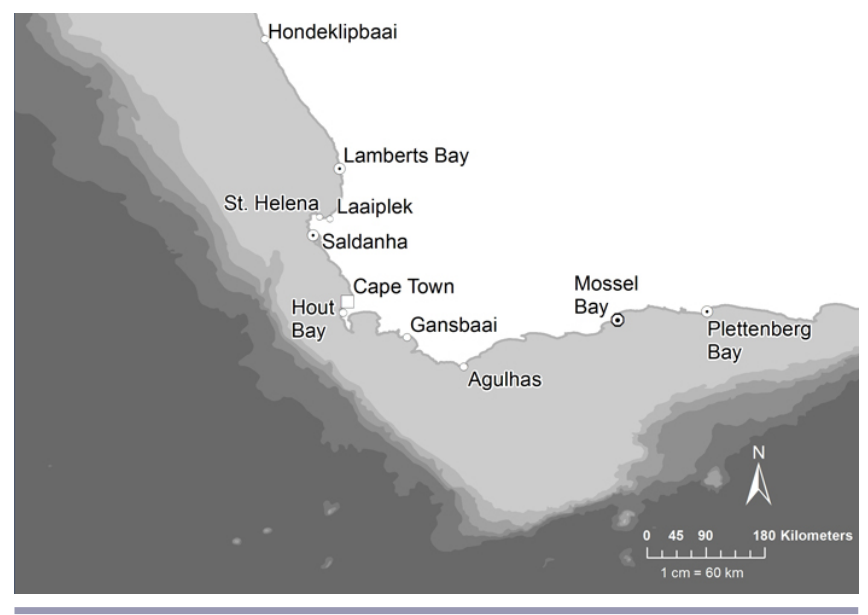

\section{PROBLEM AND METHODS}

Adopting a marine social-ecological systems approach (sensu Berkes 2011, Ommer et al. 2011), we explore the iterative interdependencies between natural marine and human social subsystems of which the South African small pelagics fishery is a part. Drawing on published literature and students' theses (Schultz 2010, Anderson 2011, Rogerson 2011, Duggan 2012, Ragaller 2012), in which the methodologies are explained in detail, as well as a number of additional formal, semistructured interviews in Gansbaai, Saldanha, St. Helena, and Lamberts Bay with both factory and fleet managers as well as informed community members, we seek to understand: (1) if major changes in the marine subsystem (long-term, systemscale) always precede changes in the social subsystem (or vice versa); (2) how pronounced such changes need to be to spill over to the other; and (3) whether these are anomalies (sudden strong deviation from average conditions, lasting only for a short period of time), regime shifts (sudden shift from one fairly stable state to another, where various components of the system are affected and the time frame for the change to occur is relatively short) or gradual changes that eventually reach a tipping point.

\section{RESULTS}

\section{Historical changes in the natural subsystem of the southern Benguela}

The decadal-scale changes documented by marine ecologists are commonly subdivided into environmental regime shifts, which refer to changes in the physical and chemical properties of the system that may or may not affect single biotic components, or ecosystem regime shifts, which indicate longterm changes in several biotic components of the system.

\section{Environmental regime shifts}

A review of the scientific knowledge of the general environmental (i.e., oceanographic) conditions in the highly dynamic environment of the southern Benguela upwelling ecosystem shows no unidirectional change from the 1950s to the present (Hutchings et al. 2012). Large variability, however, has been observed throughout this period, and at various scales: seasonal, interannual, and decadal. Change in dynamic natural systems is initially observed by oceanographers as anomalies, which can be of short duration (an abnormally hot or windy month, for example) or may extend over several years or even decades. For example, an environmental short-term anomaly noted by fishers and government scientists alike (for example, Buys 1959, Eigelaar 1999) was a short period of cold water in St. Helena Bay during 1955/6. This caused a change in the activity of bioluminescent zooplankton, used in the fishing industry before the time of echo sounders as an indicator of small pelagic fish activity, as well as decreased availability of sardines. A subsequent multiannual warmer period co-occurred with that increased sardine recruitment and created a boom in the sardine fishery that came to a sudden end in the early 1960s.

Interannual variability (including anomalies) is of interest in the generation of fisheries management advice in South Africa's small pelagics fishery, in that scientists combine the size of the parent fish stock with environmental conditions that relate to survival during early life history stages, in order to generate an estimate of recruitment strength (e.g., Miller and Field 2002). This estimate, along with the numbers of resultant young fish that enter the fishery (recruits), allows scientists to calculate an annual estimate of total allowable catch (TAC), because pelagic fish live only two to five years, so the recruitment of young fish has an important influence on population size and variability. Sophisticated modeling can be part of this process (e.g., de Moor et al. 2011). For strategic fisheries management, however, following King and McFarlane (2006), it is useful to know whether a phase of "generally favorable" or one of "generally detrimental" environmental conditions for small pelagic recruitment and availability can be determined. The long-term (decadal-scale) changes in the dynamics of small pelagic fish in turn influence predation patterns in the associated marine food webs (Shannon et al. 2003, Watermeyer et al. 2008, Osman 2010), 
creating positive or adverse conditions for critically dependent predators such as Cape gannets (Morus capensis) and the threatened African penguin (Spheniscus demersus, which specialize in sardine and anchovy (see, e.g., Hutchings et al. 2012 and references therein, Cury et al. 2011), as well as setting a "general" backdrop for the fishery and therefore for management advice.

Decadal-scale environmental regime shifts on the west coast were identified by Howard et al. (2007), and Shannon et al. (2010) for 1958-68 (increased sea surface temperature (SST)), 1971-81 (increased upwelling, i.e., an environmental regime detrimental to sardine and favoring anchovy), 1991-2001 (decreased upwelling and increasing SST off the northern part of the west coast, i.e., conditions more favorable for sardine recruitment) and in the early 2000s (further increasing SST/ reduced upwelling). These results were confirmed by Blamey et al. (2012), who further refined the analyses of Howard et al. (2007) and Roy et al. (2007) to indicate increased variability of upwelling at the west coast since 1996 (a situation detrimental to sardine), and increased upwelling (i.e., productivity) at the south coast in the period 1996-2003, in line with increased availability and recruitment of small pelagics along the south coast.

\section{Regime shifts at the ecosystem scale}

Based on these findings, Howard et al. (2007) postulated two regime shifts at the scale of the pelagic ecosystem, one in the early 1960s, following the collapse of the sardine population on the west coast (fishery-induced), and the other in the early 2000s, indicated by a shift in the relative abundance of small pelagics from the west coast to the south coast in a situation of very high population sizes of both species (likely environmentally-induced). Blamey et al. (2012) added to these findings an ecosystem regime shift in the inshore in the first half of the 1990s, when the majority of the rock lobster catches moved from the west coast to the southwest coast, the spatial change impacting, through mechanisms related to predation and habitat provision, sea urchins and abalone as well as cormorants. The shift in the inshore may have been induced by reduced oxygen in the bottom waters (Cockcroft et al. 2008), exacerbated by a few short-term, bay-scale low oxygen events causing mass walkout of rock lobster, particularly in the 1990s (Cockcroft et al. 2008). This in turn resulted in considerably reduced biomasses of rock lobster in the St. Helena Bay/Saldanha Bay area. Alternatively (or additionally as we cannot yet be certain), an increase in illegal or unreported fishing pressure, unaccounted for in assessment models, that has possibly occurred since the 1980s could have contributed to the inshore regime shift.

\section{Periods of change in the human social subsystem}

\section{Restructuring at the scale of the small pelagic fishing} industry

On the back of declining rock lobster catches and the Californian sardine stock collapse, but with large amounts of fish being found in St. Helena Bay, the South African small pelagic industry grew rapidly. The industry is based on economies of scale, producing very large amounts of fish efficiently at low per unit value, in contrast to the small-scale, inshore rock lobster and hand-line fisheries that operate on comparatively smaller amounts of fish with higher per-unit value. The small pelagics fishery used the business networks and processing (canning) experience created through the export-oriented rock lobster industry, the structure of which had matured by the early 1930s (Lees 1969). Lamberts Bay, for example, at the northern end of St. Helena Bay, which was to become the center of the small pelagic fishing industry, had had a rock lobster processing factory since 1918. Political and economic (capital) support by the government's Fisheries Development Co-operation (FDC), established in 1944, helped, as did foreign investment, partly driven by deteriorating fishing in the North Sea (Lees 1969). Links with the Californian sardine fishery had been established since 1935 (through visits there to learn about fish processing), and the first Californian-built reduction plant was erected in Lamberts Bay in 1947. The fishery then targeted sardine and horse mackerel (Trachurus capensis) for canning and reduction, using small wooden boats inshore (Figures 2A, B) with a "kopman" (head man) standing at the bow at night looking out for the bioluminescence that indicated to them where to set their nets (Eigelaar 1999).

The structure of the industry left room for individual entrepreneurship, as demonstrated when Johnnie Eigelaar pioneered the use of echo sounders during two years of cold water (1956/57), with which the entire fleet was rapidly equipped. Even though the number of boats fishing leveled off (Stander and Le Roux 1968), this actually masked increased fleet catching efficiency. After 1958, bigger vessels with larger hold capacity were employed (Stander and Le Roux 1968), reaching a maximum size in the early 1970s (Butterworth 1983), perhaps in response to signs of collapse of the northern Benguela sardine population in the late 1960s, coupled with the collapse of the Peruvian anchoveta in the early 1970s. The warmer period from 1958 had initiated good sardine recruitment, and the modernized fleet permitted huge catches of mostly sardines until 1963; these amounted to up to 400,000 tons per year (Stander and Le Roux 1968). Although centered on St. Helena Bay, the fishery began to extend southward to Gansbaai, which had been modernizing since the early 1950s. A fishing cooperative was established, again with financial aid by the FDC (see Ragaller 2012 for an overview), and an additional reduction plant opened there in 1962, building on existing infrastructure left over from shark liver processing during the Second World War. Whereas the fishery before 1956 had focused on adult sardine (mean age 5 years or older (Butterworth 1983), after 1967 it increasingly caught juveniles (Stander and Le Roux 1968), along with two to three year-old sardines of 16-20 cm length (Butterworth 1983). Many rock lobster and sardine canneries as well as fish meal plants began to consolidate into a few, largely still family- 
owned, companies, as access to these resources became possible.

Fig. 2. A. Early west coast sardine boat (from Davies 1957 as reproduced in Hutchings et al. 2012). B. Velddrif, in St. Helena Bay, during the times of rapid growth in the small pelagic fishing industry (early 1950s) (from http:// trawlerheritage.co.za/Fishing\%20Harbours\%20and\% 20Factories/AIF\%20Velddrif/Velddrif.htm). C. Purse seiners alongside the factory jetty in Gansbaai (2010). Note older wooden vessel in the front, modern small fibreglass vessel behind.

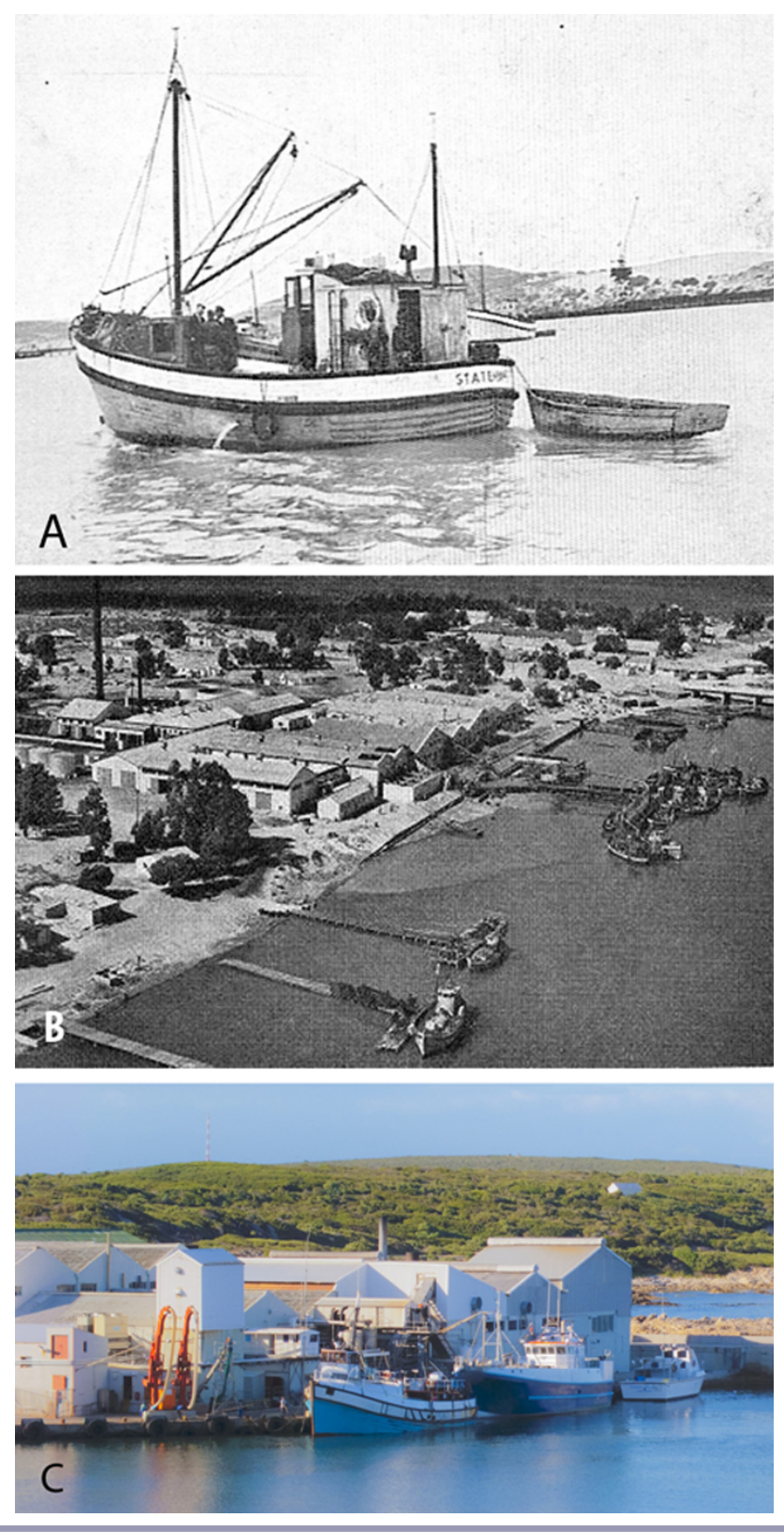

The collapse of the sardine population in the early 1960s saw several responses in the fishery, including a shift northward to Walvis Bay in Namibia (then under South African occupation), where South Africa west coast companies had operated since the 1950s. Mesh size was also reduced from 32 to $12 \mathrm{~mm}$ after 1963 (Butterworth 1983) to target anchovy (for fish meal and oil), with catches increasing from around $150,000 \mathrm{t}$ in 1965-1971 to around 250,000 $\mathrm{t}$ in 1972-1982. The southern expansion of the South African small pelagics fishery (first to Gansbaai and then further onto the Agulhas Bank (Butterworth 1983), as well as a diversification in catches to include chub mackerel (Scomber japonicus) for canning, produced overall fish catches of between 350,000 and 500,000 t until the early 1980s (Butterworth 1983).

In the wake of the sardine collapse in the 1960s, the industry restructured, becoming vertically and horizontally integrated (Raakjaer Nielsen and Hara 2006). Eigelaar (1999) notes that he and his brother would buy businesses that were unrelated to fishing at the end of every year, so as not to be dependent on the risks of changing fish stocks. Large investment companies invested in the smaller fishing companies and diversified their holdings in a process that was typical of the search for increasing profitability at that time (Lipschitz 1989). A closer look at the shareholders of companies and key business reports (Brimstone Investment Corporation 2011, Oceana Group Limited 2011, Sea Harvest undated, Tiger Brands 2011) shows the more recent structure of the industry. Oceana, for example, (now one of the biggest fishmeal and canning companies in South Africa) has $37.5 \%$ of its shares owned by Tiger Brands, which, in turn, is one of South Africa's largest food companies with R20 Billion revenue for the 2009 financial year. Brimstone Investment Corporation has a $9.7 \%$ shareholding in Oceana as well as in Sea Harvest (another large, hake fishing company) and shares in Tiger Brands, which means that Brimstone has a second, indirect portion of shares in Oceana. Tiger Brands is horizontally integrated, controlling many different business interests (mayonnaise, bread, retail shops and health care, for example), some of which are the result of foreign investments, with products that go well beyond the confines of the fishing towns and are linked to agriculture and tertiary services, such as critical care. Both Sea Harvest and Oceana are vertically integrated, owning most of the production chain, from the boats that catch the fish to the factories that process it and the subsequent cold storage. This restructuring points to a consolidation of corporate power in the fishery.

While the collapse of the Peruvian anchoveta fishery in the early 1970s and the corresponding good prices for fish meal certainly helped to encourage targeting anchovy, following van der Lingen et al.'s (2006a) reasoning, the fishery probably also benefitted from increased anchovy recruitment in the cold ocean environment after 1971, although this cannot be proved as no recruitment data were collected during the 1970s. 
Overall, the fishing industry did well in the 1970s, because of its spatial extension, good prices for fishmeal, and continued canning using chub mackerel to partially compensate for sardine.

In the 1990s and 2000s, the shift from "owner skippers" of pelagic fishing vessels to company ownership continued, with companies maintaining the vessels and hiring skippers on a commission basis, at the same time "squeezing" independent operators through control of the processing facilities. The process continues today under the new long-term rights: new entrants, for the most part small quota holders, are dependent on the established industrial firms and their processing facilities (Raakjaer Nielsen and Hara 2006), which have sufficient capacity to process the current catches.

However, as the distribution of sardine changed after 1997 and particularly after 2001 (Fairweather et al. 2006, Hutchings et al. 2012), large quantities of fish caught off the south coast had to be trucked back to the processing factories on the west coast. This proved too expensive for some of the smaller factories (e.g., Premier in Saldanha and Oceana in Lamberts Bay), which subsequently closed. A new canning and reduction factory was constructed in Mossel Bay (see Figure 1), which opened in 2007 after a multiyear planning process, but it drew its workers from the south coast. Fish caught west of Cape Agulhas are still processed in the west coast factories, however, meaning longer steaming distances and requiring good chilling facilities on the vessels. The large companies that operate modern steel vessels can shuffle vessels between the Namibian and South African fleets, and have thus been able to adapt to the situation. However, these changes might lead the large companies to outcompete the smaller purse seine fleet in Gansbaai (Figure 2C), which continues to operate its smaller boats as a cooperative.

\section{Regulatory aspects: the national scale}

The Sea Fisheries Act of 1940 promoted development of industrialized fishing. Some conservation thinking, however, was present from the onset of the small pelagics fishery in the 1940s, partly because of the effects of bottom trawling, and partly because of the collapse of the Californian sardine and its fishery. Limitations on processing capacity and a minimum mesh size were put into place in 1950, and a short closed season was implemented in 1951 (Butterworth 1983). A combined total allowable catch of 227,000 $\mathrm{t}$ for sardine and horse mackerel was legislated from 1953-1959, but only loosely enforced. In the wake of the collapse of the sardine fishery, minimum mesh size was reduced from 32 to $12 \mathrm{~mm}$ in 1963 (Butterworth 1983), in order to allow the fishery to target anchovy. A combined total allowable catch (TAC) for all purse seined species was implemented from 1971, ranging between 360,000 and 450,000 t.

A new Sea Fisheries Act came into place in 1973 and empowered the management authority, represented by the minister (of Economic Affairs, then Agriculture and Fisheries, then Environmental Affairs and Fisheries), to regulate any aspect of the fishing industry (Butterworth 1983). Butterworth (1983:337) notes that:

Despite continuous scientific advice towards
greater caution, perhaps the most significant
management restrictions - the re-imposition of a
quota in 1971, andits decrease in 1977 -correspond
to the two collapse periods of the neighbouring
[Namibian sardine] resource, which presumably
engendered a more safety-conscious attitude in the
SA management authority.

In 1975, company-specific quotas were introduced to avoid "first come first served" fishing, which can lead to excess fishing effort. The declaration of a $200 \mathrm{nmi}$ EEZ in 1976 may have helped conservation thinking, and the commissioning of a new research vessel, the "Africana", in the early 1980s, as well as funding support for ecosystem-oriented research through the Benguela Ecology Program that started in the same period (Moloney et al. 2004) can also be seen in this light. Additionally, the new Act made provisions for Marine Protected Areas. In the 1980s, the R/V Africana made improved fisheries surveys possible, while in the mid-1980s the continued low abundance of sardine led to specific TACs for sardine and anchovy, replacing the global TAC: a conservative management strategy aiming at rebuilding the depleted sardine population.

The infamous Rubicon speech given by South Africa's then president P.W. Botha in 1985, which constituted a reaffirmation of the National Party's commitment to an apartheid state, resulted in swift trade reprisals: the following year, international sanctions closed down most export possibilities. For the industrial-scale rock lobster fishery this resulted in catches being transshipped offshore as "of South Atlantic origin", since they had not touched South African soil: this made monitoring and control more difficult, and opened the way to catch under-reporting (see below).

In 1988, a new Sea Fisheries Act established a Quota Board to remove the TAC "from the political arena" (Chief Directorate Marine Development 1993), and a Fisheries Advisory Committee (with membership representing specific sectors and appointment based on expertise), which replaced the Sea Fisheries Research Fund by the Sea Fisheries Fund, which had wider application. The Quota Board also came to allocate access rights (as opposed to only TACs) in various fisheries, as detailed in Isaacs (2006). Following democracy in South Africa, this Act was followed by the Marine Living Resources Act of 1998, which sought to balance marine conservation thinking with social and economic objectives, including the correction of past injustices in resource access. In the first half of the 2000s, medium- and long-term fishing rights were given for a number of fisheries, including small 
pelagics, rock lobster, abalone, and hand-line. Van Sittert and Hauck (2006) introduced a series of reviews of this hotlydebated process.

Building on the former Fisheries Advisory Committee, the Consultative Advisory Forum (CAF) was established, consisting of experts from different sectors of industry, and including scientists who are independent of the government institute. CAF was to oversee management advice from the various sector-specific working groups. The CAF would also consider advice and information from recognized representative fishery bodies, specifically, recommendations on the annual TAC and operational management plans (Republic of South Africa 1998). CAF also advised on the allocation of research funds for multidisciplinary research. This broadened scope pointed to a more system-oriented approach to fisheries management. The council was, however, disbanded in the mid-2000s and remains so, leaving only sector-specific advice reaching the minister.

Changes at the scale of the fishing communities

The growth of the rock lobster industry into the 1930s along the west coast had been supported by a government that needed to employ large numbers of people in the interwar period (van Sittert 2002). At that time, many poor people moved to the west coast for work, although it was not a hospitable place to settle. The land adjacent to the cold Benguela current running along the west coast is semi-arid, freshwater was hard to come by and electricity was not then available. The result of these and other difficulties was malnutrition and disease (typhoid epidemics) (Lees 1969). Moreover, fishers could barely survive on the money they made harvesting rock lobster. Although people could subsist and/or trade on a small scale using the abundant west coast marine food sources, the state supported job-creating industries and the rapid expansion of a large-scale, multi-species export fishery. Before the companies arrived, some of the places that would become large industrial fishing centers had had no settled human presence, while at other sites (such as St Helena Bay, Laaiplek and Lamberts Bay) people had been involved in small-scale linefishing and gill-netting. However, the goal of industry was to create profits from fish exported halfway across the globe.

St. Helena Bay, Lamberts Bay and Gansbaai's fishers all experienced the effects of changing fishing techniques and regulations. The economic boom of the small pelagics fishery, beginning in the late 1940s, brought with it large employment opportunities and increased local populations in and around the coastal towns. In the 1950s in Gansbaai, a drop in international and national demand for shark liver products and decreasing value of the local hand-line fishery had left the town struggling (Barnard 1986, Ragaller 2012); investment in the small pelagic industry would give it another chance. Catching and processing small pelagic fish requires considerable capital investment, forcing fishers to specialize, investing their time and effort in purse seining for these fish, and leaving aside rock lobster, abalone, hand-lining, and angling. At the same time, state regulations enshrined the idea of specialist fishers (such as purse seiners and hand-liners) rather than protecting the flexible strategy of drawing on multiple species throughout the year. This followed the state tactic of allocating fishing rights as widely as possible, in order to allow new entrants into the fishery.

The fishers of Gansbaai (Ragaller 2012), Lamberts Bay (Rogerson 2011) and St. Helena Bay (Schultz 2010) have been frustrated by the constraints imposed on them by these regulations, which force them into categories and attempt to dictate how they fish. In all three places, research shows that fishers consider fishing to be an intimate part of their life, not something that can be reduced to seeing themselves as merely purse seiners or hand-liners or any one category of fisher (or fishing technique). From the 1950s through the 1980s, the pelagics fishery used to close for one to three months (sometime between August and December). During this time, the factories closed and the fishing vessels did not operate. Workers and crew could then practice their alternative fishing: inshore line-fish and rock lobster. More recently, pelagic fishing has become more year-round, with a short maintenance break (usually in December). This has brought more continuous employment, or at least less well defined and shorter periods of closure, which have helped to decrease the mobility of Gansbaai's purse seine crew around the western Cape (snoeking on the west coast), and to further increase dependency on the factory (Ragaller 2012). In short, industrial restructuring has affected the livelihoods of people in St. Helena Bay (Schultz 2010), Lamberts Bay (Rogerson 2011) and Gansbaai (Ragaller 2012), as well as their engagement with the ocean.

It is important to note that people's relationship with the sea is not limited to resource extraction. Industrial development brought with it land and sea pollution in and around the communities. At Laaiplek the first fish meal was produced in 1944 from the offal of bokkom (salted and air-dried harders, Liza richardsonii) production (Lees 1969), since much of the waste was disposed of in trenches behind the factories or dumped back into the ocean. Increasing hygiene standards and the nuisance value of the waste compelled factories to address the problem, particularly through the recovery of fish meal from the wastewater produced in the fish canning process. By 1950 Laaiplek had the first "stick water" recovery plant, which allowed the recovery of solids from the wastewater produced in the fish canning process, thus significantly increasing the percentage of meal produced from the same amount of fish. By 1956 almost all of the 19 reduction plants in the Cape and Walvis had adopted this process, simultaneously increasing the cost effectiveness of the fish meal production and the quality of the discharged wastewater. In the 1990s, further improvements were implemented through the introduction of 
"dry offloading" in which no water is added when fish are pumped from boat to factory. The resulting "blood water" formed by damaged fish and melting ice water remains in the holds and is discharged some distance offshore. Despite these considerable improvements, nearshore water and habitat quality remain a concern to the present day.

The large-scale, rapid expansion of the fish meal and canning industries brought an influx in labor to sustain the expansion in processing (Lees 1969). Incoming black and colored laborers came either from among those forced out of the Cape Town area by the apartheid regime's Native Urban Areas Act, or from those who left the homelands in the Eastern Cape Province seeking an alternative to employment in large-scale mining in the former Transvaal province. Most of them ended up in distinct "communities" tied to specific fish factories that controlled the land they occupied (Lees 1969, van Sittert 2003), with jobs but without the development that could carry them out of shantytowns.

Technological advances, market demand, fish supply, and high postwar unemployment had allowed the industrial small pelagic industry to expand along the "undeveloped" west coast. However, people working in factories or on boats under increased licensing regulation became tied to one place and one kind of work, whereas previously they would have subsisted on, or sold a variety of, ocean species: snoek, gelbek, harders, rock lobster, and abalone, depending on season and availability. Industrial fisheries brought modernization, the cash-and-goods economy and the apparent security of fixed salaries. However, the flexibility of pre-industrialized life was lost. The occupational pluralism that used to reside with individuals and families was moving up the organizational hierarchy to companies. It became the companies that acquired flexibility by practicing a range of activities selected according to the availability of resources. Skippers and crews were paid by the ton, factory workers by the hour, thereby allowing companies to expand and contract operations and hence expenditures, according to the amount of fish being caught.

When rock lobster stocks and prices began to fall, there was work for those people in the small pelagics sector as it began to expand, and effort was moved to the offshore waters. However, problems arose if the people relying on the cash income of factory work ever had to turn to subsistence catches, as could happen in the variable small pelagics fishery. Businesses, by contrast, were flexible, with a range of activities that let them move finances around during slumps. The state relied on companies to develop much of the housing and schooling for their workers, but people lacking stable income and basic necessities (such as freshwater) had little room to maneuver. Reforms in the 1990s helped; some places (Saldanha, St. Helena, and Lamberts Bay) developed limited alternatives, such as tourism or work in an iron ore terminal. Fishing companies now provide good benefits through (for example) share options and medical aid (Van Zyl et al. 2008), but these still do not protect people from resource variability and decline. When large reductions in TAC force companies to downsize or (as in Saldanha and Lamberts Bay) close the factory (Figure 3), benefits then also stop, and alternative incomes or subsistence have to be found.

Fig. 3. Lambert's Bay harbor A. Active purse seiner fleet in the 1990s (from http://trawlerheritage.co.za/Fishing\% 20Harbours \%20and\%20Factories/Lambertsbaai/Lamberts\% 20Bay.htm). B. 2012, remaining small boats after conversion of the cannery to potato processing.
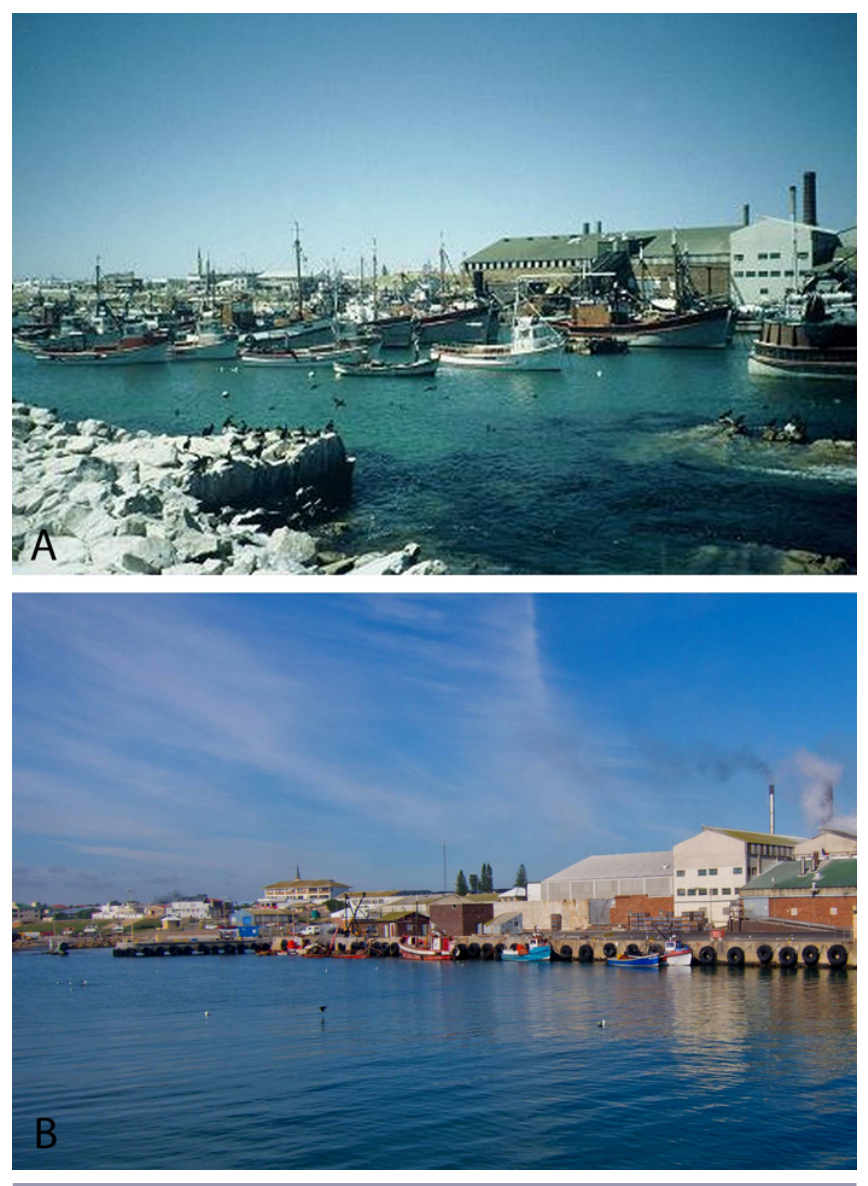

One problematic alternative is poaching, especially rock lobster and abalone, which are nutritious and sell well. Many poach to put food on the table; others (especially small-scale and subsistence fishers) regard these species as part of a multigenerational fishing activity that has only recently become illegal (Schultz 2010) and whose sudden denial is a considerable challenge. There are also organized poaching syndicates that sell large quantities of abalone on international markets for very good prices; links have been drawn between these and international drug trafficking, local gangs, and drug dealers (Steinberg 2005). It is difficult to determine to what 
extent poaching is a lucrative organized, criminal activity (Steinberg 2005), but to date fishers who poach for relatively little money or for subsistence face the same penalties as organized gangs.

\section{DISCUSSION}

\section{Interdependencies}

Interdependencies of the natural and human subsystems in the 1940s through the 1980s

The ecological and the social are iteratively interdependent systems. Additionally, we argue that the distinction between offshore and inshore natural subsystems commonly made by biologists needs to be abandoned. The fishing industry, obviously, depends on its resource base: it was the abundance of small pelagics fish at the west coast that supported the development of their fishery. Environmental perturbations (like the 1956/7 cold anomaly) influence catch magnitude and composition. The warm period that followed led to increased sardine recruitment, allowing good fishing. The coupling between the human and natural subsystems, has been relatively tight (effects being felt within a year or two, in line with the short life span of small pelagics).

Fishing also influences its resource base; sustained fishing pressure has gradually changed the population size and age structure of sardine at the west coast (Butterworth 1983), with overfishing causing an abrupt stock collapse and initiating an ecosystem regime shift that also influenced such top predators as seabirds (Crawford et al. 1983) and also food web structure (Watermeyer et al. 2008). Through the 1980s, the industry was central to many people's livelihoods in a period of decreased fish availability. This had the effect of deteriorating living conditions as resource options shrunk. The ongoing pollution of inshore habitats through processing of offshore resources increased these concerns. Simultaneously, increased corporate efficiency meant fewer jobs. The ramifications of job loss in the context of apartheid development, and export driven, free market capitalism left many people in the fishing towns in dire circumstances, without a social safety net of basic income, health, housing, and utilities.

While the international sanctions that followed P. W. Botha's Rubicon speech might have been a blessing for overharvested resources such as rock lobster (the apparent drastic decrease in demand could have allowed rock lobster to recover), a change in product labeling made it possible to continue the export fishery. Rock lobster catch rates and catches began to increase, although only after 2001 (Groeneveld 2003, Cockcroft et al. 2008).

This occurred with the establishment of a new management procedure (Moloney and Johnston 2002, Johnston and Butterworth 2005), but also with the end of a large and longstanding poaching operation. In 2001 Hout Bay Fishing
Industries (HBFI) had become involved in a two-year court case in New York in which HBFI faced accusations of smuggling illegally caught rock lobster (mainly South Coast rock lobster Palinurus gilchristi, plus an unknown proportion of West Coast rock lobster, Jasus lalandii) and Patagonian tooth fish (Dissostichus eleginoides) into the US over at least 15 years from about 1986 on (Neumeister 2003). The company held about $30 \%$ of the rock lobster quota for the south coast, but had poached about double their quota: "Assistant US attorney Marcus Asner [...] called it 'a case that involved hundreds of thousands of kilograms of seafood' [...]" (IOL News 2003). This poaching followed the Rubicon speech and took place despite significant international sanctions, capital flight, and a massive devaluation of the South African currency (Cape Business News 2005, McKeown 2011). All of these possibly explain the initial motivation, for not only was trade, (especially to the US) almost nonexistent, but the underhand nature of the transactions meant that, although the exchange rate was in favor of exports, larger amounts of seafood had to be sold to make a meaningful profit. These organized poaching operations demonstrate how the apartheid regime created situations in which fishing companies "creatively" survived. Such operations outlived apartheid and continued well into the post-1994 era, even when international trade was reestablished. That said, it was the political economy of the 1980s that allowed poaching to take the shape it did, enriching a select few but damaging not only the resources but also the lives of inshore, small-scale fishers struggling with depleted rock lobster stocks.

\section{Interdependencies of the natural and human social subsystems: the wider picture}

While people in the west coast fishing communities have been left disillusioned by the empty promises of the new postapartheid South African state, and many have resorted to poaching as a form of survival and protest, that behavior is likely to compromise the needed rebuilding of resources on the west coast, including rock lobster and some line fish (Griffiths 2000). Industry, meanwhile, continues the strategy of species expansion (to redeye round herring and mesopelagic light- and lanternfish-family Myctophidae) and effort increase (from purse seining to midwater trawling), which is the same strategy that had led to resource depletion in the 1960s and 1970s. Additionally, larger amounts of nontarget species are caught in midwater trawling than in purse seining, with this bycatch possibly increasing the ecosystem effects of a future small pelagics fishery. Evaluations of the ecosystem state of the southern Benguela indicate that changes to date may still be reversible (Cury and Shannon 2004, Shannon et al. 2009, Osman 2010), but continued depletion of ecosystem components and erosion of the resource base for the fisheries may well lead to drastic changes in ecosystem functioning such as have been observed in the northern Benguela (Cury and Shannon 2004) and in the Black Sea (Oguz and Gilbert 
2007), from which economic recovery is severely compromised. In short, the social-ecological system of the South African west coast currently is in a less than desirable state, likely compromising its resilience to large-scale change in the future.

South Africa is not alone in facing these pressures. Worldwide, coastal communities have been in rapid increase, although the strictly rural population in South Africa is leveling off (Small and Nicholls 2002, Kok and van Tonder 2011). Kok and van Tonder (2011:16) point out that "the relationship between population and the environment is [...] far more complex than sometimes expected". With inland retirees moving to the coast, inshore fishing pressure, or demand for inshore resources, may well increase in the future. Thus, the demographic development of coastal areas, as well as patterns in fish demand and consumption, need to be analyzed relative to changes in the productive capacity of the marine ecosystem. In South Africa, the state's reform push for industrialization in the 1940s had been part of wider, international ideological drives for state social welfare. In the 1990s, it was driven by the impetus to redistribute work and access in the fisheries away from white hands (van Sittert 2002). Yet these attempts have an "uncanny resemblance", as van Sittert (2002) argues, to one another. In both cases the state was trying to redistribute part of the fishery into the hands of the majority, in the form of jobs and/or access rights. Both times, the state was driven by social welfare approaches to alleviate the growing urban poor and "poverty of the fishing hamlets" (van Sittert 2002:298).

Yet this never worked out. In both periods market-oriented approaches were used to address poverty alleviation and redistribution. In the earlier period, companies became the institutional structures that looked after workers' education, housing, and even water. The factories thus were peoples' frame of reference for most things and in some instances were also addressed as the magisterial authority (Lees 1969). With reduced work in factories, factory product change (from canned sardines to potato chips in Lamberts Bay, for example: Figures 3A, B) or closure, the structure they provided for people's lives has weakened considerably. Continued departmental silos in the government have failed to provide a replacement structure, and government thus so far has failed to achieve its objectives on job creation and poverty alleviation, while continuing to place marine ecosystems and marine resources at risk through overexploitation. Both Schultz (2010) and Rogerson (2011) indicate that those factory workers and small-scale fishers who have remained are hardest hit by the highly variable small pelagic industry, in line with McCay et al's (2011) findings on changes in the US surf clam fishery under environmental change. Aggravating the situation at South Africa's west coast in the early 2000s, the new and, in view of the need to rebuild depleted resources, restricted allocation of fishing rights that limits fishing to specific categories, has been detrimental to the flexible livelihood strategies people employed at earlier points and to an extent still do today (Hutchings et al. 2002, Ragaller 2012). Recent studies internationally (McCay et al. 2011) point out that security of access rights and the ability to diversify as a form of adaptation to change are crucial.

\section{Some coping strategies}

Using four contrasting case studies, Perry et al. (2011) summarize the difference in responses of marine socialecological systems to short- and long-term stress. Importantly, they highlight how long-term stress makes it impossible to continue short-term coping responses such as intensification and diversification of effort, spatial shifts of fishing, or simply "riding out the storm". Long-term adaptive responses include life history changes and restructuring of the natural subsystem, typically leading to increased variability. In the human social system, such long-term adaptive responses include political reform, social restructuring, capacity building, and community closure, leading to decreasing flexibility. We have shown that two periods of long-term, system-scale change in the west coast ecological system (the 1960s and 1990s) decreased resilience. Each carries their own history, yet the latter happened in a context underpinned by events in the former. The collapse of sardine over the 1960s meant that other species (anchovy and club mackerel) were added to the target repertoire ("short-term" response sensu Perry et al. 2011), but in the long term, this prevented recovery. Fish were and currently are targeted ever more efficiently, adding to the strains already created by regime shifts, maintaining long-term stress.

One might expect that environmental changes will be most influential at longer time scales, i.e., decades, because shorter term environmental variability is being coped with. In contrast, social changes might be expected to be most influential on shorter time scales, i.e., annual to decadal, because of the immediate requirements of food and profit. However, this does not seem to apply to the west coast system. For example, the buildup of the sardine fishery during the 1950s saw people switching gradually from inshore to offshore employment. The collapse of sardine in the early 1960s, which might have resulted in a rapid redeployment of the workforce in the canneries, was mitigated by switching to alternative species, notably chub mackerel. It was only after the second regime shift in the early 2000s that the sudden absence of small pelagics from the west coast got factories to close quickly, following erosion of the local resource base. The interactions between the two subsystems appears to happen on multiple spatial and temporal scales in parallel, and the sudden changes characteristic of ecosystem regime shifts emphasize the importance of their tipping point as a signal for long-term change in the human social subsystem. 
We have also shown how the observed system-scale changes in both human and natural subsystems compounded problems across subsystem boundaries rather than mitigating them. In the language of systems modeling, as adopted in McCay et al. (2011), the negative effects of deviations (from a given situation of relative stability, i.e., regime) were amplified rather than dampened. In the new millennium, west coast fishers experienced a loss of access to inshore fishing and/or small quotas on top of an already strained fishing industry in light of the sardine regime shift and the closing of two factories. The inadequate implementation of livelihood diversification strategies make the closure of a fishing community that has existed since the rock lobster fishery of the early $20^{\text {th }}$ century a concrete possibility. Successful management strategies will facilitate adaptation to changed circumstances and prevent practices that aggravate negative effects of change.

Ecosystem regime changes are closely felt on the ground in perhaps unexpected ways. The closure of factories at Lambert's Bay (Figure 3) and Saldanha Bay demonstrates this in the context of fishers' dependence on the factories for which they work. Reduced ability to move within the ecosystem, both spatially and across species, by being tied to the factory means that fishers continued to rely heavily on fishing companies for their livelihood, also in post-1994 South Africa. While employees enjoy benefits such as pension, medical aid and share options, these disappear with closing factories. However, factories do not close overnight. The gradual process of shrinking the workforce to save costs adds another dimension to the question of variability, and variable fish stocks and markets make cut-and-dry decisions about livelihoods difficult.

Hence, it is only if people can be flexible that they will be able to make adjustments to the way they deal with environmental change. Over the last two decades, the west coast has developed some alternative industries such as tourism that provide employment, but these are few in number. Ommer et al. (2007) provide a critical appraisal of alternatives to extractive resource-based economies, including aquaculture, tourism, and local initiatives, and emphasize that new developments need to contribute as pathways between environmental and human health, and as routes to potential long-term community survival, if there is to be a future in them. While South Africa on the whole lends itself well to tourism, the west coast has its limitations; there are not many high-profile attractions there, particularly relative to the nearby Cape Town metropolitan area. Subsistence or local trade in fish and other species is not a promising approach, because the regulatory context needed for that does not currently exist. Instead, the large-scale commercial-industrial approach adopted by the government over the last two decades is based on global neoliberalism, which supports competitive capitalism, large factories, and corporate structure (van Sittert 2002).
Fishers who work in either the small pelagics and hand-line fisheries or both know that all aspects of the ocean and its resources are in constant flux. Research by Anderson (2011), Duggan (2012), Ragaller (2012), Rogerson (2011), and Schultz (2011) consistently shows fishers speaking of variability as opposed to long-term change. This overview of the 1940s to the present highlights the interdependencies between the human social and the natural subsystems operating on two scales: the interannual scale (encompassing recruitment and corresponding catch variability), and the multiannual/decadal scale (encompassing species dominance shifts and strategic industry adaptations, such as the introductions of echo sounders and steel vessels, and the opening and closing of factories). What is striking in this history, especially the more recent changes of the last two decades, is the multitude of concerns and livelihood strategies of fishers. People worry on a daily basis about many issues that require far more immediate attention than long-term ecosystem change. Experienced fishers have a thorough understanding of how to catch fish on their fishing grounds, and they interact with the ocean and climate intuitively. Fishing is for many a multigenerational livelihood that is the central organizing activity of daily life.

The experiences built up over their years of fishing are largely based on their observations, which have taught fishers how to deal with interannual variability, both in the human-social and in the natural subsystems. On an interannual scale, the social and the ecological relate relatively tightly and are at least semiquantitatively predictable, as shown, for example, through the current fisheries management. However, in the natural subsystem alone, the coupling operating on a multiannual scale, on top of high interannual variability, makes it difficult to predict decadal-scale, "regime" tipping points with high statistical certainty. The ecosystem regime shifts of the 1960s and the mid-1990s to early 2000s have shaken up people, and industry, beyond their built-up experience. Were it only for the natural subsystem to find a new balance after a regime shift, we would not need to be concerned. Since the natural and social systems are interconnected, however, anticipating future major perturbation, and planning for the concomitant changes, are mandatory.

Managing for resilience at a variety of scales is key (Folke 2006, Ommer et al. 2007, Perry et al. 2011, Ommer et al. 2012), requiring a solid relationship between fishers, state managers and scientists, and academic scientists. In the South African context, these stakeholder categories are not necessarily disjunct as Anderson (2011), Ragaller (2012) and Duggan (2012) indicate, which on the one hand adds to the fluidity of the situation, but on the other, opens possibilities for productive collaboration. Addressing only one aspect of what is clearly a complex problem will not improve matters. Rationalizing large-scale industrial fisheries such as this small pelagics fishery through neoliberal market-oriented 
approaches has the potential to ensure profitable companies, but at the cost of the livelihoods of fishers and factory workers who then have to find alternatives (sometimes even poaching), and increases in angling and hand-lining have put immense pressure on line fish. The lesson is that what may be economically most efficient in the short term on a global market can, over the long term, generate an ecological disaster in which those who most depend on accessing fish resources are most affected.

Awareness of the opportunity to nurture viable livelihoods in the face of long-term change makes diversification a plausible starting point, if it is planned for properly. Again, this means that we must understand both the natural and the social subsystems involved, recognize their interdependence, and plan accordingly. The complexity of the situation requires that management explore various future scenarios strategically, while maintaining or increasing resilience. Increased research on the social (human dimensions), predictive modeling in a systems context (e.g., Smith et al. 2011, Starfield and Jarre 2011), and collaboration among several stakeholders (e.g., Paterson et al. 2010, Shannon et al. 2010, Field et al., 2013), taken together, point to possible ways to open up a more positive future.

In South Africa in particular, this implies overcoming the established atmosphere of deep mistrust especially between fishers and "the state". Whereas there is an established communication between the large companies and government scientists and management authorities, and while the large companies are well represented in scientific and management fora, this is not the case for the smaller quota holders or the inshore fishers. The apartheid legacy of mistrust persists, preventing these groups from establishing their own organizations through which they could enter and influence the management system. Social-ecological researchers have found that this is a common thread running throughout their work, whether they are of government or academic affiliation.

We submit that collaborative research can ease confrontation and eventually open the doors to collaborative management. To work, this has to start with mutual respect. Fishers are experienced in their profession. Understandings sometimes diverge between the professional perspectives of fishers and researchers. In the latter, "objective" data covering a wide range of variables are collected such that the results can be duplicated by other researchers. Hence, scientists' interpretations of variability can differ from those of fishers, who rely on their considerable place-based insights and training. The ideal situation occurs when these opinions and interpretations begin to converge, acknowledging each partner's credibility. While collaborative research in South Africa is in its infancy, a few promising possibilities have recently been initiated, including work with rock lobster fishers at the west coast and with hand-line fishers at the south coast.

\section{CONCLUSIONS}

The boom in the pelagics fisheries in the late 1950s and early 1960s coincided with environmental conditions favorable for sardine. However, intense overexploitation led to its collapse shortly thereafter, initiating spin-offs both in the wider ecosystem as well as in the human social system. The capitalintensive pelagic industry remained economically viable by consolidating the financial structure and diversifying the resource base and catch location. The second major ecosystem shift in the late 1990s/ early 2000s occurred at the same time as a regime shift in the human social subsystem with the advent of democracy. Again large industry adapted, generating some employment in the east, but the impact of the ecological regime shift was generally deleterious in the west. This went along with decreased availability of and access to, inshore resources due to resource depletion and the social shift of post-apartheid policy, leaving coastal communities in a precarious state. The continued decline of inshore resources has put this part of the coast on a knife-edge due broadly to two coproducing aspects. On the one hand more permanent changes and interannual fluctuations have left the offshore resources scarcer; on the other hand, in concert with these changes, people have become more reliant on the inshore as a livelihood alternative or supplement. The closing of two factories in the early 2000s made very clear that people had few options in terms of access and resource availability. The small capital investment structure that characterizes the inshore industry is less flexible and hence less able to deal with resource scarcity. This precarious situation in the off- and inshore natural subsystems means that even relatively small changes in either have a significant impact on people's lives.

We have therefore seen that while major, system-scale perturbations will impact across both subsystems, regardless of where they initiate, the local social system (as opposed to the corporate one) is less able to cope. In contrast, seasonal and interannual variability are easier to cope with because they can be buffered within each of the subsystems. The west coast social-ecological system has learned to deal with seasonal and interannual variability to a large extent, although prevention of erosion of the resource base in the long term needs continued focus. In contrast to interannual variability, long-term systemscale changes are beyond the experiential frame of reference of the linked social-ecological system and will require careful scenario planning in order to prevent the collapse of systems that we know to be in an already stressed situation.

So far, these stressors have manifested through decadal-scale variability. However, unidirectional climate change, when it happens, will add another layer of complexity by further changing the resource base as well as having an impact on the people in coastal towns. Management of in- and offshore 
resources as biologically distinct communities needs to be revisited. The ecological distance between, for example, hake and rock lobster might be sufficient to warrant drawing such a line. However, the highly interwoven approach people take to fishing binds the actions of people within discreet industries to the various species of fish. Longer term, decadal fluctuations, and the growing concerns around unidirectional change in ecological/environmental "states" have brought this to the fore, not least because of the plight of peoples' situations. Such complexity requires careful planning through concerted efforts by natural and social scientists, fishers, community leaders, and the fishing industry. They are linked, as we have shown, and need to begin to plan together. Generating possibilities for meaningful communication is paramount, and collaborative research is suggested as a promising way forward.

Responses to this article can be read online at: http://www.ecologyandsociety.org/issues/responses. php/5917

\section{Acknowledgments:}

This study was made possible through the South African Research Chair Initiative, funded by the Department of Science and Technology and administered by the National Research Foundation, through the Research Chair in Marine Ecology and Fisheries (AJ). It is a contribution to the project "Defragmenting African Resource Management (DARMA)", for which contract funding to S. Ragaller is gratefully acknowledged, as well as to the Benguela Nansclim project ("Climate effects on biodiversity, abundance and distribution of marine organisms"), funded by the Norwegian Aid Department (NORAD). We thank Jaco Louw for access to the wonderful current and historic resources he is curating through http://www.trawlerheritage.co.za. The conversations with skippers, fishers, factory managers, and community members are highly valued and will hopefully continue sooner rather than later. Greg Duggan and Jennifer Rogerson are thanked for constructive discussions. We thank Dr. Rosemary E. Ommer for the invitation to present this study in her theme session at the XVIth World Economic History Congress.

\section{LITERATURE CITED}

Anderson, T. 2011. Tracking the movement of fish: skipper's logbooks and marine knowledges in fisheries management. Thesis. Department of Social Anthropology, University of Cape Town, Cape Town, South Africa.

Barnard, E. 1986. 'n kutluurhistoriese Beeld van Gansbaai en Omgewing. Thesis. University of Stellenbosch, Stellenbosch, South Africa.
Berkes, F. 2011. Restoring unity: the concept of marine socialecological systems. Pages 9-28 in R.E. Ommer, R. I. Perry, K. Cochrane, and P. Cury, editors. World fisheries: a socialecological analysis. Fish and Aquatic Resource Series 14, Wiley-Blackwell, Oxford, UK. http://dx.doi.org/10.1002/9781444392241.ch2

Blamey, L. K., J. A. E. Howard, J. Agenbag, and A. Jarre. 2012. Regime-shifts in the southern Benguela shelf and inshore region. Progress in Oceanography 106:80-95. http:// dx.doi.org/10.1016/j.pocean.2012.07.001

Brimstone Investment Corporation. 2011. Integrated Report 2011. [online] URL: http://www.brimstone.co.za/

FinancialResults/2011/Brimstone ir 11.pdf. Accessed 25/10/2013.

Butterworth, D. 1983. Assessment and management of pelagic stocks in the southern Benguela region. FAO Fisheries Report No. 291, Volume 2:329-405. Food and Agricultural Organization of the United Nations, Rome, Italy.

Buys, M. E. L. 1959. Hydrographic environment and commercial catches 1950-57. Division of Fisheries Investigational Report No. 37. Division of Fisheries of the Department of Commerce and Industries, Pretoria, South Africa.

Cape Business News. 2005. The tale of two speeches. [online] URL: http://www.wcbn.co.za/viewg.php?id=1412. Accessed 25/10/2013.

Chief Directorate Marine Development. 1993. 55 th annual report for the calendar year 1987. Government Printer, Pretoria, South Africa.

Cockcroft, A., D. van Zyl, and L. Hutchings. 2008. Largescale changes in the spatial distribution of South African West Coast rock lobsters: an overview. African Journal of Marine Science 30(1):149-159. http://dx.doi.org/10.2989/

AJMS.2008.30.1.15.465

Crawford, R. J. M, P. A. Shelton, and L. Hutchings. 1983. Aspects of variability of some neritic stocks in the southern Benguela system. FAO Fisheries Report No. 291, Volume 2:407-448.

Cury, P. M., I. L. Boyd, S. Bonhommeau, T. Anker-Nilssen, R. J. M. Crawford, R. W. Furness, J. A. Mills, E. J. Murphy, H. Oesterblom, M. Palenczny, J. F. Piatt, L. J. Shannon, and W. J. Snydeman. 2011. Global seabird response to forage fish depletion - one third for the birds. Science 334:1703-1706. http://dx.doi.org/10.1126/science.1212928

Cury, P., and L. J. Shannon. 2004. Regime shifts in upwelling ecosystems: observed changes and possible mechanisms in the northern and southern Benguela. Progress in Oceanography 60:223-243. http://dx.doi.org/10.1016/j.

pocean.2004.02.007 
Davies, D. H. 1957. The South African pilchard (Sardinops ocellata): size composition of the commercial catches, 1950-55. Division of Fisheries Investigational Report No. 26. Division of Fisheries of the Department of Commerce and Industries, Pretoria, South Africa.

de Moor, C. L., D. S. Butterworth, and J. A. A. De Oliveira. 2011. Is the management procedure approach equipped to handle short-lived pelagic species with their boom and bust dynamics? The case of the South African fishery for sardine and anchovy. ICES Journal of Marine Science 68:2075-2085. http://dx.doi.org/10.1093/icesjms/fsr165

Duggan, G. 2012. In the realm of the kob kings: rethinking knowledges and dialogue in a small-scale fishery. Thesis. Department of Social Anthropology, University of Cape Town, South Africa.

Eigelaar, J. 1999. As die Skipper op de voorstewe staan. Nasionale Boekdrukkery, Goodwood, Western Cape Province, South Africa.

Fairweather, T. P., C. D. van der Lingen, A. J. Booth, L. Drapeau, and J. J. van der Westhuizen. 2006. Indicators of sustainable fishing for South African sardine (Sardinops sagax) and anchovy (Engraulis encrasicolus). African Journal of Marine Science 28:661-680. http://dx.doi.org/10.2989/18$\underline{142320609504215}$

Field, J. G., C. G Attwood, A. Jarre, K. Sink, L. J. Atkinson, and S. Petersen. 2013. Cooperation between scientists, NGOs and industry in support of sustainable fisheries: the South African hake Merluccius spp. trawl fishery experience. Journal of Fish Biology 83(4):1019-1034. http://dx.doi. org/10.1111/jfb.12118.

Folke, C. 2006. Resilience: the emergence of a perspective for social-ecological systems analysis. Global Environmental Change 16:253-267. http://dx.doi.org/10.1016/j.

gloenvcha.2006.04.002

Griffiths, M. H. 2000. Long-term trends in catch and effort of commercial line fish off South Africa's Cape Province: snapshots of the $20^{\text {th }}$ century. South African Journal of Marine Science 22:81-110. http://dx.doi.org/10.2989/025776100784125663

Groeneveld, J. C. 2003. Under-reporting of catches of south coast rock lobster Palinurus gilchisti, with implications for the assessment and management of the fishery. African Journal of Marine Science 25:407-411. http://dx.doi. org/10.2989/18142320309504030

Howard J. A. E., A. Jarre, A. Clarke, and C. L. Moloney. 2007. Application of the sequential t-test algorithm for analysing regime shifts to the southern Benguela ecosystem. African Journal of Marine Science 29(3):437-451. http://dx.doi. org/10.2989/AJMS.2007.29.3.11.341
Hutchings, L., A. Jarre, T. Lamont, M. van den Berg, and S. P. Kirkman. 2012. St Helena Bay (southern Benguela) then and now: muted climate signals, large human impact. African Journal of Marine Science 34:559-583. http://dx.doi. org/10.2989/1814232X.2012.689672

Hutchings, K., S. J. Lamberth, and J. K. Thurpie. 2002. Socioeconomic characteristics of gillnet and beach-seine fishers in the Western Cape, South Africa. South African Journal of Marine Science 24:243-262. http://dx.doi.org/10.2989/025776102784528646

IOL News. 2003. Former Cape Town fishing boss in US dock. August 7. [online] URL: http://www.iol.co.za/news/southafrica/former-cape-town-fishing-boss-in-us-dock-1.110971\#. UBt3L YgfH8. Accessed 09/11/2012.

Isaacs, M. 2006. Small-scale fisheries reform: expectations, hopes and dreams of "a better life for all". Marine Policy 30 (1):51-59. http://dx.doi.org/10.1016/j.marpol.2005.06.010

Johnston, S. J., and D. S. Butterworth. 2005. Evolution of operational management procedures for the South African West Coast rock lobster (Jasus lalandii) fishery. New Zealand Journal of Marine and Freshwater Research 39:687-702. http://dx.doi.org/10.1080/00288330.2005.9517345

King, J. R., and G. A. McFarlane. 2006. A framework for incorporating climate regime shifts into the management of marine resources. Fisheries Management and Ecology 13:93-102. http://dx.doi.org/10.1111/j.1365-2400.2006.00480. $\underline{\mathrm{x}}$

Kok, P. C., and L. van Tonder. 2011. Human population trends in South Africa. Pages 12-16 in L. Zietsman, editor. Observation on environmental change in South Africa. SUN MeDIA, Stellenbosch, South Africa.

Lees, R. 1969. Fishing for fortunes: the history of the South African fishery and the men who made it. Purnell, London, UK.

Lipschitz, S. 1989. Pollution control investment decisions and policy preferences of senior managers of the Southern African fish processing industry. Dissertation. Environmental and Geographical Science, University of Cape Town. South Africa.

McCay, B. J., W. Weisman, and C. Carolyn. 2011. Coping with environmental change: systemic responses and the roles of property and community in three fisheries. Pages 381-400 in R. E. Ommer, R. I. Perry, K. Cochrane, P. Cury, editors. World fisheries: a social-ecological analysis. Wiley Blackwell, UK. http://dx.doi.org/10.1002/9781444392241. $\underline{\operatorname{ch} 23}$ 
McKeown, J. 2011. Playing with fish. Rhodes University News. October 11. [online] URL: http://www.ru.ac.za/ latestnews/name,43708,en.html. Accessed 09/11/2012.

Miller, D. C. M., and J. G. Field. 2002. Predicting anchovy recruitment in the southern Benguela ecosystem: developing an expert system using classification trees. South African Journal of Science 98(9/10):465-472.

Moloney, C. L., and S. J. Johnston. 2002. Using decision analysis to evaluate candidate OMPs for the South African west coast rock lobster fishery. South African Journal of Science 98:461-464.

Moloney, C. L., C. D. van der Lingen, L. Hutchings, and J. G. Field. 2004. Contributions of the Benguela Ecology Programme to pelagic fisheries management in South Africa. African Journal of Marine Science 26:37-51. http://dx.doi. org/10.2989/18142320409504048

Neumeister, L. 2003. SA men reeled into New York court on fish smuggling charges. Mail and Guardian. August 7. [online] URL: http://mg.co.za/article/2003-08-07-sa-menreeled-into-new-york-court-on-fish-smuggling-charges. Accessed 09/11/2012.

Oceana Group Limited. 2011. Integrated report. [online] URL: http://www.oceana.co.za/sites/default/files/ar/ oceana 2011 full integrated report web.pdf. Accessed 25/10/2013.

Oguz, T., and D. Gilbert. 2007. Abrupt transitions of the topdown controlled Black Sea pelagic ecosystem during 1960-2000: evidence for regime-shifts under strong fishery exploitation and nutrient enrichment modulated by climateinduced variations. Deep-Sea Research Part I 54(2):220-242. http://dx.doi.org/10.1016/j.dsr.2006.09.010

Ommer, R. E., and the Coasts Under Stress research project team. 2007. Coasts under stress: restructuring and socialecological health. McGill-Queen's University Press, Montreal, Canada.

Ommer, R. E., R. I. Perry, K. Cochrane, and P. Cury, editors. 2011. World fisheries: a social-ecological analysis. WileyBlackwell, Chichester, UK. http://dx.doi.org/10.1002/9781444392241

Ommer, R. E., R. I. Perry, G. Murray, and B. Neis. 2012. Social-ecological dynamism, knowledge, and sustainable coastal marine fisheries. Current Opinion in Environmental Sustainability 4(3):316-322. http://dx.doi.org/10.1016/j. cosust.2012.05.010

Osman, W. 2010. Trophic model-generated indicators of the southern Benguela ecosystem for communicating with fisheries managers. Thesis. Department of Zoology, University of Cape Town, South Africa.

Paterson, B., M. Isaacs, M. Hara, A. Jarre, and C. L. Moloney. 2010. Transdisciplinary co-operation for an ecosystem approach to fisheries: a case study from the South African sardine fishery. Marine Policy 34:782-794. http://dx.doi. org/10.1016/j.marpol.2010.01.019

Perry, R. I., R. E. Ommer, M. Barange, S. Jentoft, B. Neis, and U. R. Sumaila. 2011. Marine social-ecological responses to environmental change and the impacts of globalization. Fish and Fisheries 12:427-450. http://dx.doi.org/10.1111/ j.1467-2979.2010.00402.x

Raakjaer Nielsen, J., and M. Hara. 2006. Transformation of South African industrial fisheries. Marine Policy 30:43-50. http://dx.doi.org/10.1016/j.marpol.2005.06.002

Ragaller, S. 2012. Misunderstandings in fisheries: an ethnography of regulative categories and communication around Dyer Island. Thesis. Department of Social Anthropology, University of Cape Town, Cape Town, South Africa.

Republic of South Africa. 1998. Marine Living Resources Act No. 18 of 1998. As amended by The Marine Living Resources Amendment Act 68 of 2000.

Rogerson, J. J. M. 2011. Above the surface, beneath the waves: contesting ecologies and generating knowledge conversations in Lamberts Bay. Thesis. Department of Social Anthropology. University of Cape Town, Cape Town, South Africa.

Roy, C., C. D. van der Lingen, J. C. Coetzee, and J. R. E. Lutjeharms. 2007. Abrupt environmental shift associated with changes in the distribution of Cape anchovy Engraulis encrasicolus spawners in the southern Benguela. African Journal of Marine Science 29(3):309-319. http://dx.doi. org/10.2989/AJMS.2007.29.3.1.331

Schultz, O. 2010. Belonging on the West Coast: an ethnography of St Helena Bay in the context of marine resource scarcity. Thesis. Department of Social Anthropology, University of Cape Town, Cape Town, South Africa.

Sea Harvest Corporation. Undated. Ownership. [online] URL: http://www.seaharvest.co.za/corporate/business. Accessed 09/11/2012.

Shannon L. J., M. Coll, and S. Neira. 2009. Exploring the dynamics of ecological indicators using food web models fitted to time series of abundance and catch data. Ecological Indicators. 9(6):1078-1095.

Shannon, L. J., A. Jarre, and S. L. Petersen. 2010. Developing a science base for implementation of the ecosystem approach to fisheries in South Africa. Progress in Oceanography 87 (1-4):289-303. http://dx.doi.org/10.1016/j.pocean.2010.08.005

Shannon, L. J., C. L. Moloney, J. G. Field, and A. Jarre. 2003. Trophic flows in the southern Benguela during the 1980s and 1990s. Journal of Marine Systems 39: 83-116. http://dx.doi. org/10.1016/S0924-7963(02)00250-6 
Small, C., R. J. Nicholls. 2002. A global analysis of human settlement in coastal zones. Journal of Coastal Research 19 (3):584-599.

Smith, A. D. M., C. J. Brown, C. M. Bulman, E. A. Fulton, P. Johnson, I. C. Kaplan, H. Lozano-Montes, Marzloff, L. J. Shannon, Y. J. Shin, and J. Tam. 2011. Impacts of fishing lowtrophic level species on marine ecosystems. Science 333:1147-1150. http://dx.doi.org/10.1126/science.1209395

Stander, G. F., P. J. Le Roux. 1968. Notes on the fluctuations of the commercial catch of the South African pilchard (Sardinops ocellata), 1950-65. Investigational Report no. 65. Division of Sea Fisheries of the Department of Industries, Sea Point, Cape Town, South Africa.

Starfield, A. M., and A. Jarre. 2011. Interdisciplinary modeling for an ecosystem approach to management in marine social-ecological systems. Pages 105-119 in R. E. Ommer, R. I. Perry, K. Cochrane, P. Cury, editors. World fisheries: a social-ecological analysis. Wiley-Blackwell, Oxford, UK. http://dx.doi.org/10.1002/9781444392241.ch6

Steinberg, J. 2005. The illicit abalone trade in South Africa. Institute for Security Studies. Paper 105. [online] URL: http:// www.issafrica.org/uploads/105.PDF. Accessed 09/05/2013.

Tiger Brands. 2011. Integrated report 2011. [online] URL: http://www.tigerbrands.co.za/pdfs/reports/Tiger\%20Brands\% 20Annual\%20Report\%202011.pdf. Accessed 25/10/2013.

van der Lingen, C., L. Hutchings, J. G. Field. $2006 a$. Comparative trophodynamics of anchovy Engraulis encrasicolus and sardine Sardinops sagax in the southern Benguela: are species alternations between small pelagics fish trophodynamically mediated? African Journal of Marine Science 28(3 \& 4):465-477. http://dx.doi.org/10.2989/18142$\underline{320609504199}$

van der Lingen, C. D., L. J. Shannon, P. Cury, A. Kreiner, C. L. Moloney, J. P. Roux, and F. Vaz-Velho. 2006b. Resource and ecosystem variability, including regime shifts, in the Benguela current system. Pages 147-185 in V. Shannon, G. Hempel, P. Malanotte-Rizzoli, C. L. Moloney, and J. Woods, editors. Benguela: predicting a large marine ecosystem. Elsevier, Amsterdam, The Netherlands.

Van Sittert, L. 2002. "Those who cannot remember the past are condemned to repeat it": comparing fisheries reforms in South Africa. Marine Policy 4:295-305. http://dx.doi. org/10.1016/S0308-597X(02)00012-X

Van Sittert, L. 2003. The tyranny of the past: why local histories matter in South African Fisheries. Ocean and Coastal Management 46:199-219. http://dx.doi.org/10.1016/S0964-5691 (02)00135-7
Van Sittert, L., and M. Hauck. 2006. Editorial introduction: post-apartheid marine fisheries in South Africa: through the ten-year looking glass. Marine Policy 30:1-2.

Van Zyl, H., T. Barbour, and R. Hamann. 2008. Assessment of socio-economic impacts of sea harvest's operations on Saldanha Bay and the West Coast District. Thesis. University of Cape Town, Cape Town, South Africa.

Watermeyer, K. E., L. J. Shannon, and C. L. Griffiths. 2008. Changes in the trophic structure of the southern Benguela before and after the onset of industrial fishing. African Journal of Marine Science 30(2):351-382. http://dx.doi.org/10.2989/ AJMS.2008.30.2.11.561 